\title{
Patrycja Gwóźdź
}

Uniwersytet Marii Curie-Skłodowskiej w Lublinie

likolid987@op.pl

\section{Umowa faktoringu na gruncie ustawy o podatku dochodowym od osób fizycznych i ustawy o podatku dochodowym od osób prawnych}

\author{
Factoring Agreement Under the Income Tax Act of Individuals and \\ the Law on Income Tax from Legal Persons
}

\section{STRESZCZENIE}

Przedmiotem niniejszego opracowania jest opodatkowanie umowy faktoringu podatkiem dochodowym od osób fizycznych i podatkiem dochodowym od osób prawnych. Tekst określa skutki podatkowe, jakie wywołuje umowa faktoringu dla zawierających ją podmiotów. Przepisy obu ustaw są ze sobą zbieżne, dlatego artykuł opiera się głównie na ustawie o podatku dochodowym od osób prawnych. Jest to możliwe, ponieważ umowa faktoringu dotyczy głównie przedsiębiorców. Każda istotna kwestia jest popierana licznymi stanowiskami organów podatkowych.

Słowa kluczowe: faktoring; podatek dochodowy od osób fizycznych; podatek dochodowy od osób prawnych

Kluczem do rozważań nad kwestią skutków umowy faktoringu w podatkach dochodowych jest zauważalna zależność, że przepisy zarówno ustawy o podatku dochodowym od osób fizycznych ${ }^{1}$, jak i ustawy o podatku dochodowym od osób prawnych $^{2}$ są ze sobą zbieżne. W związku z tym znacznie prościej jest zrozumieć istotę opodatkowania faktoringu podatkiem dochodowym na gruncie ustawy o po-

1 Ustawa z dnia 26 lipca 1991 r. o podatku dochodowym od osób fizycznych (t.j. Dz.U. z 2012 r., poz. 361), dalej jako: u.p.d.o.f.

2 Ustawa z dnia 15 lutego 1992 r. o podatku dochodowym od osób prawnych (t.j. Dz.U. z 2014 r., poz. 851), dalej jako: u.p.d.o.p. 
datku dochodowym od osób prawnych, ponieważ faktorem zazwyczaj są osoby prawne. Ten rodzaj umowy nienazwanej najczęściej dotyczy przedsiębiorców.

Przy umowie faktoringu stosuje się te przepisy u.p.d.o.p., które dotyczą sprzedaży praw majątkowych, jakimi są wierzytelności. Faktorant mocą umowy przenosi na faktora konkretne prawo majątkowe, czyli wierzytelność. Zgodnie z art. 12 ust. 3 u.p.d.o.p. za przychody związane z działalnością gospodarczą i działami specjalnymi produkcji rolnej, osiągnięte w roku podatkowym, uważa się także należne przychody, choćby nie zostały jeszcze faktycznie otrzymane, po wyłączeniu wartości zwróconych towarów, udzielonych bonifikat i skont. Ponadto za datę powstania przychodu, według art. 12 ust. 3a u.p.d.o.p., uznaje się co do zasady dzień wydania rzeczy, zbycia prawa majątkowego lub wykonania usługi albo częściowego wykonania usługi, nie później niż dzień wystawienia faktury albo uregulowania należności.

Istotny dla dalszych rozważań jest także przepis art. 12 ust. 3c u.p.d.o.p., zgodnie z którym jeżeli strony ustalą, że usługa jest rozliczana w okresach rozliczeniowych, za datę powstania przychodu uznaje się ostatni dzień okresu rozliczeniowego określonego w umowie lub na wystawionej fakturze, nie rzadziej niż raz w roku. Skutki, jakie umowa faktoringu wywołuje w podatkach dochodowych, są ściśle związane z wynagrodzeniem za realizację jej podstawowych funkcji, przy czym może być ono ustalone odrębnie dla każdej z poszczególnych funkcji. Charakter wynagrodzenia należnego faktora $\mathrm{w}$ związku $\mathrm{z}$ realizacją funkcji tej umowy powoduje, że skutki podatkowe na gruncie podatku dochodowego są odmienne. Chodzi tutaj o określenie chwili powstania przychodu u faktora oraz przedstawienie w rachunku podatkowym kosztów u faktoranta. W przypadku funkcji usługowej o charakterze ciągłym przychód po stronie faktora powstaje, zgodnie $\mathrm{z}$ art. 12 ust. 3c u.p.d.o.p., w ostatni dzień okresu rozliczeniowego określonego w umowie lub na wystawionej fakturze, nie rzadziej niż raz w roku. Po stronie faktoranta koszt uzyskania przychodu powstanie wraz z poniesieniem wydatku zgodnie z kwestiami wynikającymi z art. 15 ust. $4 d$ i 4e u.p.d.o.p.

Funkcja finansowa jest związana $\mathrm{z}$ faktoringiem właściwym i niewłaściwym. W zależności od tego przychód u faktora powstanie inaczej. Przychód powstanie w momencie spłaty wierzytelności przez dłużnika (faktoring) lub gdy faktorant spłaci wierzytelność, a następnie zwrotnie ją przeniesie (faktoring), zgodnie z art. 12 ust. 4 pkt 2 u.p.d.o.p. $\mathrm{U}$ faktoranta koszt uzyskania przychodu powstanie $\mathrm{z}$ chwilą przelewu wierzytelności. W związku z realizacją funkcji gwarancyjnej przychód u faktora powstanie najpóźniej w chwili przelewu wierzytelności. Wynagrodzenie, jakie otrzyma faktorant w związku z realizacją funkcji, należy traktować jako koszt uzyskania przychodu z chwilą jego poniesienia, czyli w dniu, w którym koszt został zaksięgowany, zgodnie z art. 15 ust. 4 e u.p.d.o.p. ${ }^{3}$

3 R. Jurkiewicz, Wierzytelność i dług, Warszawa 2013, s. 168-169. 
Zgodnie ze stanowiskiem Naczelnego Sądu Administracyjnego dla podmiotów świadczących usługi faktoringowe przedmiotem opodatkowania umowy podatkiem dochodowym jest dochód będący nadwyżką przychodów nad kosztami ich uzyskania ${ }^{4}$. Według art. 14 ust. 1 u.p.d.o.p. przychodem z odpłatnego zbycia rzeczy lub praw majątkowych co do zasady jest ich wartość wyrażona w cenie określonej w umowie przez strony. Jeżeli jednak cena bez uzasadnionej przyczyny znacznie odbiega od wartości rynkowej tych rzeczy lub praw, przychód określa organ podatkowy w wysokości wartości rynkowej. Kosztem uzyskania tego przychodu, według jednego z poglądów doktryny, jest wartość nominalna zbywanej wierzytelności, która naturalnie pomniejsza majątek przedsiębiorcy, a także wydatki, jakie ponosi faktorant, czyli prowizja i odsetki dyskontowe. Gdy nastąpi zbycie wierzytelności poniżej wartości jej kupna, u faktoranta wytworzy się strata. W związku z powyższym, zgodnie $\mathrm{z}$ art. 16 ust. 1 pkt 39 u.p.d.o.p., strata nie może zostać uznana za koszt uzyskania przychodów z tytułu odpłatnego zbycia wierzytelności, chyba że uprzednio - w myśl art. 12 ust. 3 u.p.d.o.p. - wierzytelność została zarachowana jako przychód należny ${ }^{5}$. Wówczas cena zapłacona przez nabywcę nie jest przychodem podatnika, ponieważ wierzytelność została już uwzględniona w podstawie opodatkowania. $\mathrm{W}$ przeciwnym razie doprowadziłoby to do podwójnego opodatkowania.

Im mniejsza jest cena wierzytelności, tym większa jest strata stanowiąca koszt uzyskania przychodów. Pogląd ten można odnaleźć w wyroku Wojewódzkiego Sądu Administracyjnego we Wrocławiu z dnia 26 czerwca 2003 r. Sąd ten stwierdził, że uprzednie zarachowanie jako przychodu należności na podstawie art. 12 ust. 3 u.p.d.o.p. nie jest równoznaczne $z$ uzyskaniem przychodu w tym okresie sprawozdawczym, gdyż przychód ten może powstać dopiero w następnych okresach sprawozdawczych, w których będą wykonywane dostawy towarów i usług, na poczet których zarachowano należności. Przychodem ze sprzedaży wierzytelności u osób prawnych, dla których obrót wierzytelnościami nie stanowi przedmiotu działalności gospodarczej, jest wartość wyrażona w cenie określonej w umowie sprzedaży prawa majątkowego, jakim jest wierzytelność art. 14 ust. 1 u.p.d.o.p. Ponadto przychodem z umowy faktoringu jest wartość wierzytelności wyrażona w cenie określonej w umowie sprzedaży. Kosztem uzyskania tego przychodu jest natomiast wartość nominalna zbywanej wierzytelności i ewentualne poniesione wydatki w postaci prowizji i odsetek ${ }^{6}$.

4 Zob. wyrok NSA Ośrodka Zamiejscowego we Wrocławiu z dnia 1 września 1999 r., I SA/ Wr 116/98.

5 Zob. wyrok NSA Ośrodka Zamiejscowego we Wrocławiu z dnia 1 września 1998 r., I SA/ Wr 973/98, „Glosa” 1999, nr 4, s. 30.

6 Zob. wyrok WSA we Wrocławiu z dnia 26 czerwca 2003 r., I SA/Wr 387/01. W niniejszej sprawie odnosi się on do przychodu $\mathrm{z}$ rat leasingowych. 
Drugi pogląd zakłada, że faktorant uprzednio zaliczył wierzytelność do przychodów należnych, zaś zapłata od faktora jest jedynie spłatą tej należności zaliczoną wcześniej do przychodów ${ }^{7}$. Za takim rozstrzygnięciem stoją również organy podatkowe. Naczelnik Drugiego Urzędu Skarbowego w Rzeszowie w swoim piśmie z dnia 20 grudnia 2006 r. wskazał, że środki pieniężne otrzymane przez Spółkę od faktora są jedynie zapłatą za fakturę, która - jak już wcześniej wspomniano - została opodatkowana podatkiem dochodowym od osób prawnych. Należność ta nie może stanowić przychodu podatkowego, gdyż powtórnie zostałaby opodatkowana tym podatkiem ${ }^{8}$. Podobne stanowisko zajął Dyrektor Izby Skarbowej w Katowicach w interpretacji indywidualnej z dnia 29 kwietnia 2009 r., w której stwierdził, że wyzbycie się przez spółkę wierzytelności na rzecz faktora, w zamian za otrzymanie kwoty wierzytelności w ustalonej wysokości, powinno być dla spółki obojętne z punktu widzenia przychodowego, jeżeli wierzytelność (wartość netto dokumentującej ją faktury) została uprzednio rozpoznana jako przychód należny. Nie ma przy tym znaczenia, jaka będzie kwota wypłacona spółce przez faktora, a w szczególności to, czy kwota ta będzie wyższa od wartości netto faktury dokumentującej daną wierzytelność. Efektem podatkowym transakcji faktoringu będzie jedynie rozliczenie przez spółkę kosztów poniesionych na rzecz faktora9 ${ }^{9}$.

Faktor, zgodnie z art. 12 u.p.d.o.p., w związku z prowadzoną przez siebie działalnością gospodarczą, nabywając wierzytelności, uzyskuje przychód należny, choćby nie został jeszcze faktycznie otrzymany. Przychodem jest więc wartość nominalna nabytej przez faktora wierzytelności oraz wysokość jego wynagrodzenia. Opozycyjnie istnieje jednak dosyć kontrowersyjny pogląd prezentowany przez Ministra Finansów, według którego nominalna kwota nabytej wierzytelności nie jest przychodem należnym wpływającym na wysokość dochodu do opodatkowania $^{10}$. Organy podatkowe prezentują jednak pierwszy pogląd, czego wyrazem jest wyrok Naczelnego Sądu Administracyjnego z dnia 14 listopada 2008 r., w którym Sąd stwierdził, że nominalna wartość zakupionych wierzytelności nie stanowi przychodu należnego. Mimo że nabywca wierzytelności staje się wierzycielem, to do czasu faktycznej realizacji wierzytelności nie uzyskuje przychodu. Wydatki na nabycie wierzytelności nie stanowią wtedy kosztów uzyskania przychodu. Przychód pojawia się natomiast z chwilą faktycznej realizacji wierzytelności, czyli w chwili

7 Pismo Ministra Finansów z dnia 28 marca 1996 r., PO 2/4-8010-01407/94, „Biuletyn Skarbowy" 1996, nr 6, s. 8.

8 Pismo Naczelnika Drugiego Urzędu Skarbowego w Rzeszowie z dnia 20 grudnia 2006 r., nr II US. I. PB/423-8/06.

9 Zob. interpretacja indywidualna Dyrektora Izby Skarbowej w Katowicach z dnia 29 kwietnia 2009 r., nr IBPBI/2/423-127/09/AM.

10 Pismo Ministra Finansów z dnia 23 kwietnia 1997 r., PO 3-IP-722-218/97, „Serwis Podatkowy" 1998, nr 4, s. 44; pismo Ministra Finansów z dnia 29 lutego 1996 r., PO 3/722-7/HS/96, „Biuletyn Skarbowy” 1996, nr 5, s. 17. 
dokonania jakiejkolwiek wpłaty przez dłużnika. Jednocześnie Spółka winna ustalić koszty uzyskania przychodu proporcjonalnie do odzyskanych kwot wierzytelności.

Podobne stanowisko znajduje się w interpretacji prawa podatkowego Drugiego Śląskiego Urzędu Skarbowego w Bielsku-Białej z dnia 23 listopada 2005 r. ${ }^{11}$, w którym stwierdzono, że przychodem w obrocie wierzytelności są otrzymane pieniądze. Oznacza to, że dla nabywającego (kupującego) wierzytelność przychodem będzie kwota wyegzekwowana od dłużnika bądź kwota uzyskana w dalszej jej sprzedaży, ale dopiero $\mathrm{w}$ dniu jej zapłaty. Zgodnie z art. 12 ust. 3a u.p.d.o.p. datą powstania przychodu należnego jest co do zasady dzień wydania rzeczy, zbycia prawa majątkowego lub wykonania usługi albo częściowego wykonania usługi, nie później niż dzień wystawienia faktury albo uregulowania należności. Dochody polskich podatników według u.p.d.o.p., które wynikają z faktoringu, są opodatkowane na zasadach ogólnych, tj. stawką 19\%.

Warto wspomnieć także o zagadnieniu niedostatecznej kapitalizacji, które zostało uregulowane $\mathrm{w}$ art. 16 ust. 1 pkt 60 i 61 oraz art. 16 ust. 6-7b u.p.d.o.p. Zaznaczyć należy, że odsetki od pożyczek udzielonych polskiej spółce przez inny powiązany z nią podmiot nie będą kosztami uzyskania przychodu, gdy podmioty udzielające pożyczki posiadają co do zasady co najmniej $25 \%$ udziałów lub akcji pożyczkobiorcy oraz kiedy zadłużenie z tytułu pożyczek przekroczy łącznie wartość kapitału własnego spółki otrzymującej pożyczkę w proporcji, w której wartość zadłużenia (przekraczająca wartość kapitału własnego spółki) pozostaje do całkowitej kwoty tego zadłużenia. Zadłużenie wobec podmiotów określa się na ostatni dzień miesiąca poprzedzającego miesiąc zapłaty odsetek od pożyczek. Przez pożyczkę zaś uważa się każdą umowę, w której dający pożyczkę zobowiązuje się przenieść na własność biorącego określoną ilość pieniędzy, a biorący zobowiązuje się zwrócić tę samą ilość pieniędzy. Przez pożyczkę tę rozumie się także kredyt, emisję papierów wartościowych o charakterze dłużnym, depozyt nieprawidłowy lub lokatę. Z kolei pochodnych instrumentów finansowych nie uważa się za pożyczkę w rozumieniu tego przepisu. Powstaje więc następujące zagadnienie: czy umowa faktoringu może zostać potraktowana jako umowa pożyczki? Kwestię te rozstrzygnął Dyrektor Izby Skarbowej w Warszawie w interpretacji indywidualnej z dnia 4 stycznia 2011 r. $^{12}$, który stwierdził, że umowa faktoringu nie spełnia definicji pożyczki wskazanej w art. 16 ust. $7 b$ u.p.d.o.p. i tym samym dyspozycja art. 16 ust. 1 pkt 60 u.p.d.o.p. nie znajdzie zastosowania w analizowanym stanie faktycznym. Jak zostało wskazane, przez pożyczkę dla celów niedostatecznej kapitalizacji należy rozumieć umowę spełniającą warunki (essentialia negotii) umowy pożyczki wskazane w art. 720 oraz inne czynności wskazane w art. 16

${ }_{11}$ Zob. interpretacja indywidualna Drugiego Śląskiego Urzędu Skarbowego w Bielsku-Białej z dnia 23 listopada 2005 r., nr PD/423-88/05/69559.

${ }_{12}$ Zob. interpretacja indywidualna Dyrektora Izby Skarbowej w Warszawie dnia 4 stycznia 2011 r., nr IPPB3/423-719/10-2/AG. 
ust. $7 b$ u.p.d.o.p. Następnie Dyrektor Izby Skarbowej w Warszawie stwierdził, że umowa faktoringu nie stanowi żadnej z czynności wskazanej expressis verbis przez ustawodawcę $\mathrm{w}$ art. 16 ust. $7 \mathrm{~b}$ u.p.d.o.p., zatem trzeba zbadać, czy umowa ta zawiera essentialia negotii umowy pożyczki. Zgodnie z poglądem powszechnie prezentowanym w doktrynie i judykaturze na gruncie Kodeksu cywilnego faktoring stanowi umowę sprzedaży wierzytelności na rzecz faktora, która - zgodnie z regulacją art. $510 \S 1$ k.c. - z mocy prawa wywołuje skutek w postaci przeniesienia wierzytelności na faktora. Faktoring spełnia warunki (essentialia negotii) zastrzeżone dla umowy sprzedaży, które są odrębne od essentialia negotii umowy pożyczki.

Kolejnym istotnym zagadnieniem jest podatek u źródła przychodów faktora. Stawki tego podatku zostały określone w art. 21 i 22 u.p.d.o.p. Wychodząc z założenia, że faktorem jest zagraniczny kontrahent, by zapobiec konieczności zapłaty wyższego podatku, który może wynieść nawet do $20 \%$ obniżenia należności wynikającej z faktury, musi on posiadać certyfikat rezydencji podatkowej. Zgodnie z umowami międzynarodowymi certyfikat rezydencji podatkowej może obniżyć podatek do wysokości nawet $5 \%{ }^{13}$. Oznacza to, że dochody takiego faktora zostały już opodatkowane podatkiem dochodowym w kraju, który wystawił dla niego certyfikat rezydencji. W przypadku jego braku to faktorant ponosi koszty podatku u źródła. Faktorant pobiera od faktora podatek u źródła i zgodnie z obowiązkiem płatnika przelewa go dla właściwego urzędu skarbowego wraz z adekwatną deklaracją. Ponadto musi przesłać informację dla urzędu skarbowego o wysokości osiągniętego dochodu przez zagranicznego kontrahenta na terytorium Polski, bez względu na to, czy pobrał podatek czy też nie. Istotne jest, że podatek u źródła może stanowić koszt uzyskania przychodu. Taką interpretację wydał Dyrektor Izby Skarbowej w Katowicach. W interpretacji indywidualnej z dnia 15 czerwca 2010 r. uznał, że kwota stanowiąca o równowartości podatku u źródła w ramach ubruttowienia będzie stanowić koszt uzyskania przychodów ${ }^{14}$.

\section{BIBLIOGRAFIA}

Interpretacja indywidualna Drugiego Śląskiego Urzędu Skarbowego w Bielsku-Białej z dnia 23 listopada 2005 r., $\mathrm{nr}$ PD/423-88/05/69559.

Interpretacja indywidualna Dyrektora Izby Skarbowej w Katowicach z dnia 29 kwietnia 2009 r., $\mathrm{nr}$ IBPBI/2/423-127/09/AM.

Interpretacja indywidualna Dyrektora Izby Skarbowej w Katowicach z dnia 15 czerwca 2010 r., nr IBPBI/2/423-372/10/BG.

${ }^{13}$ www.pit.pl/aktualnosci-podatkowe/1506-certyfikat-rezydencji-podatkowej-a-podatek-uzrodla-11430 [dostęp: 10.09.2016].

${ }_{14}$ Zob. interpretacja indywidualna Dyrektora Izby Skarbowej w Katowicach z dnia 15 czerwca 2010 r., nr IBPBI/2/423-372/10/BG. 
Interpretacja indywidualna Dyrektora Izby Skarbowej w Warszawie z dnia 4 stycznia 2011 r., nr IPPB3/423-719/10-2/AG.

Jurkiewicz R., Wierzytelność i dług, Warszawa 2013.

Pismo Ministra Finansów z dnia 29 lutego 1996 r., PO 3/722-7/HS/96, „Biuletyn Skarbowy” 1996, nr 5.

Pismo Ministra Finansów z dnia 28 marca 1996 r., PO 2/4-8010-01407/94, „Biuletyn Skarbowy” 1996, nr 6.

Pismo Ministra Finansów z dnia 23 kwietnia 1997 r., PO 3-IP-722-218/97, „Serwis Podatkowy” $1998, \mathrm{nr} 4$.

Pismo Naczelnika Drugiego Urzędu Skarbowego w Rzeszowie z dnia 20 grudnia 2006 r., nr II US. I. $\mathrm{PB} / 423-8 / 06$.

Ustawa z dnia 26 lipca 1991 r. o podatku dochodowym od osób fizycznych (t.j. Dz.U. z 2012 r., poz. 361).

Ustawa z dnia 15 lutego 1992 r. o podatku dochodowym od osób prawnych (t.j. Dz.U. z 2014 r., poz. 851).

www.pit.pl/aktualnosci-podatkowe/1506-certyfikat-rezydencji-podatkowej-a-podatek-u-zrodla-11430 [dostęp: 10.09.2016].

Wyrok NSA Ośrodka Zamiejscowego we Wrocławiu z dnia 1 września 1998 r., I SA/Wr 973/98, „Glosa” 1999, nr 4.

Wyrok NSA Ośrodka Zamiejscowego we Wrocławiu z dnia 1 września 1999 r., I SA/Wr 116/98.

Wyrok WSA we Wrocławiu z dnia 26 czerwca 2003 r., I SA/Wr 387/01.

\section{SUMMARY}

The subject of the present paper is the taxation of Factoring Agreement with the personal income tax and corporate income tax. The text defines tax effects caused by the Factoring Agreement for both its parties. The regulation of both acts are in line with each other. Therefore, the text is based mainly on the corporate income tax. It is possible because the Factoring Agreement applies to a particular group of entities - mostly entrepreneurs and banks. Every important issue is supported by numerous stances of the tax authorities.

Keywords: Factoring Agreement; income tax act of individuals; income tax from legal persons 